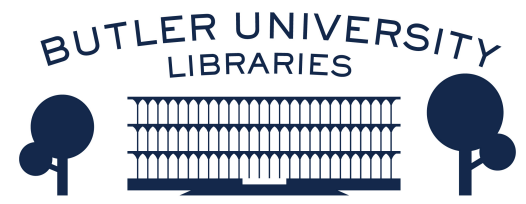

Journal of Hindu-Christian Studies

Volume 32 Discussion of Nathaniel Roberts, To

Be Cared For: The Power of Conversion and

Article 15

Foreignness of Belonging to An Indian Slum.

2019

\title{
Book Review: In the Bosom of the Father: The Collected Poems of Benedictine Mystic
}

\author{
Edward T. Ulrich \\ University of St. Thomas
}

Follow this and additional works at: https://digitalcommons.butler.edu/jhcs

\section{Recommended Citation}

Ulrich, Edward T. (2019) "Book Review: In the Bosom of the Father: The Collected Poems of Benedictine Mystic," Journal of Hindu-Christian Studies: Vol. 32, Article 15.

Available at: https://doi.org/10.7825/2164-6279.1741

The Journal of Hindu-Christian Studies is a publication of the Society for Hindu-Christian Studies. The digital version is made available by Digital Commons @ Butler University. For questions about the Journal or the Society, please contact cbauman@butler.edu. For more information about Digital Commons @ Butler University, please contact digitalscholarship@butler.edu. 
emerging Indian nationalism. Historiographers have noted a general shift, in the late nineteenth century, from social reform to nationalism. Writing during a time of rising nationalism, in the 1890s, Aurobindo Ghose criticized reformers like Sen for being shallow imitators of the West. However, according to Stevens, Sen was not a mere imitator, but was trying to embody both East and West. For instance, he kept an upper-class home but also experimented with samnyasa. Stevens believes that Sen was trying to bridge East and West by trying "to 'perform' the roles of both an Anglicised gentleman and a Hindu ascetic" (193).

What was the impact of this controversial and self-professedly eclectic figure? His organization, the Brahmo Samaj of India, later reconstituted as the "New Dispensation," died out soon after his death. Further, his efforts at social reform, his theatrical celebrations of saints, and his hybridized religious rituals, left no lasting historical tradition. Yet, he was a creative man who experimented with different streams of thought. He articulated ideas and insights that later appeared in the works of figures like Swami Vivekananda and Aurobindo Ghose. Likewise, he explored ideas that later nineteenth and twentieth century Indian Christian theologians developed more fully. Also, in Hindu-Christian Faqir (2015), Timothy Dobe shows Sen's importance in the history of hybridized Hindu-Christian asceticism.

The main aim of Stevens's study is to situate Sen in his historical context, showing how he negotiated the various transnational forces operating on him. This book is important for scholars exploring nineteenth and twentieth century intellectual encounters between India and the West. It should be a part of the libraries of scholars researching figures like Vivekananda and Brahmabandhab Upadhyay. It is especially important for those studying the nineteenth and twentieth century encounter between Hindu and Christian thought.

Edward T. Ulrich

University of St. Thomas

\section{In the Bosom of the Father: The Collected Poems of Benedictine Mystic. Translated by Jacob Riyeff. Eugene, OR: Wipf and Stock, 2018, 226 pages.}

SWAMI ABHISHIKTANANDA (Henri Le Saux, 1910-1973) was the well-known Roman Catholic priest and monk who immersed himself in Advaitic spirituality while retaining his identities as a priest and monk. He spent two decades exploring the tensions and issues that arose. Jacob Riyeff is a professor of English specializing, among other topics, in monastic and contemplative dimensions of medieval English poetry. At a retreat center, he came across Abhishiktananda's books.
Intrigued, Riyeff explored more, and thus the current publication.

Abhishiktananda did not set out to be a poet nor is he known for his poetry. However, he wrote many free verse poems in his prose works, expressing his experiences, feelings, thoughts, and struggles. Riyeff gathered all these poems and organized the book into four sections. The first consists of poems from the manuscript, "Guhantara." Abhishiktananda composed this work in the early 1950s, and it was one of his earliest attempts to wrestle, 
theologically, with Advaita. The second section consists of translations of Abhishiktananda's French adaptations of Ramana Maharshi's poems. It was through Ramana, and the symbolic importance of the holy mountain, Arunachala, where Ramana lived, that Abhishiktananda developed his fascination with Advaita. The third section consists of poems from his diary and the fourth from other prose works.

$$
\text { Riyeff comments that in }
$$
Abhishiktananda's poetry "there is an immediacy and a baldness (boldness!) of statement and observation he did not often allow himself. Here in the poems, Swāmī Abhishiktānanda lets his guard down more than he does in his prose, the monk singing out to his God, not-two" (13). Riyeff characterizes the poetry, stating that though Abhishiktananda does not use "poetic forms with regular meters," there are "several formal features, like vivid and even shocking images, ardent anaphora, and syntactic parallelism" (13). Some poems give beautiful expression to aspects of Upanishadic spirituality:

God is as close to you as you are.

God is as far from you within yourself as he is outside of yourself.

Travel the starry firmament, out beyond the galaxies, and still you will not have reached God. God's heaven is beyond all the heavens we can reach by reason or sense.

The mystery you bear within yourself is itself beyond all the galaxies your mind can explore (124).

Other poems explore the tensions Abhishiktananda experienced between Advaitic spirituality and his Christian identity. An example is in the early poem, "The Other Shore," from "Guhantara." He wrote about a disjunction between the scholarly world that nurtured him as a seminarian and monk in France and the spirituality he experienced at Arunachala:

who cares about the words scholars use to enclose

the mystery that lies within:

no one will understand who has not first seen it within himself-

who at some point has experienced those beatific death throes (47).

Although Abhishiktananda experienced the spirituality at Arunachala as something new to him, he nevertheless identified it with Jesus Christ: "I came here to make You known to my Hindu brothers,/but it is You who have made Yourself known to me in them,/in the overwhelming features of Arunāchala!" (129). Abhishiktananda explored this in a further poem: "In our teaching, we dwell on the theological or dogmatic truths about Jesus. Whose formulation-all of them-is ever and terribly dependent on a given mythic environment and intrinsically relative philosophical systems. ... Jesus is the image that arises in my deepest depths and rises up in my consciousness" (147). Whereas dogmatic statements are specific to cultures, the experience itself of Jesus has a universality, Abhishiktananda believed, rising up from depths beneath human consciousness.

One can raise a critical point. In the preceding statement, Abhishiktananda was referring to nineteenth and twentieth century attempts to get to the core of Jesus' message by "demythologizing" it, by moving past a philosophical and supernatural exterior. However, the demythologized Jesus tends to reflect the interests of the thinker conducting the demythologizing, whether that interest be social reform, aspects of Heideggerian philosophy, or, in Abhishiktananda's case, Advaitic experience. 
This book is appropriate for those interested in twentieth century mystics and contemporary expressions of Advaita. All scholars of Abhishiktananda should have it. Riyeff relied, in part, on the work of Judson Trapnell, whose research on Abhishiktananda's poetry was cut short by his untimely death in 2003. It is good that these poems are now readily available and that Trapnell's work has new life in Riyeff's.

Edward T. Ulrich

University of St. Thomas

\section{Learning Interreligiously: In the Text, In the World. By Francis X. Clooney, SJ. Minneapolis: Fortress Press, 2018, xiii + 370 pages.}

AROUND the time I read this book, I visited the Van Gogh Museum's exhibit, "Van Gogh and the Sunflowers." Visitors to the popular Amsterdam destination view the evolution of the famous painter's treatment of the large, bright blooms. Sketches and multiple versions convey a sense of the artist's process and technique. The sunflowers appear in different lighting; singly, in vases, and in fields; blooming and dropping their petals. The artist's letters to peers and family members disclose his thoughts about his craft and his feelings about the work.

Francis X. Clooney's Learning Interreligiously impresses the reader with similar glimpses into the inner workings of the artist behind his comparative theological masterpieces. This collection of posts from his blog at the "In All Things" website of the Jesuit journal America spans nearly a decade, from November 2007 to December 2016. During that time, in which Clooney published six monographs and edited volumes and wrote numerous articles, the blog posts reveal comparative theological sensibilities at work in daily life-while preparing weekly sermons, contemplating significant events, and commenting in a distinctive way upon religious and interreligious controversies as they arise.
The first half of the book consists of various series of blog posts classed as "interreligious readings." Some of these sets of reflections coincide with a liturgical seasonreading about Krishna during Advent, for example, or reading the Yoga Sutras or the Bhagavad Gita during Lent. Other series contemplate Hindu readings of Christian texts and themes, such as Yogananda's interpretations of passion week and Swami Prabhavananda's commentary on the Sermon on the Mount. Still others consider Christian themes alongside their parallels in non-Hindu texts: the Qur'an and the Book of Mormon. At times these pieces serve as a kind of digest of larger comparative theological projects. Characteristically, though, Clooney presents them not as settled conclusions, but as discrete acts of reading in two traditions in order to learn from them and ask new kinds of questions.

The posts in the second half of the book are more occasional, taking contemporary events such as key anniversaries, papal statements, controversial publications, deaths of notable figures, and matters of interreligious significance as their point of departure. Like a thread running through this section, Clooney returns to the themes of how a reader can approach unfamiliar material, avoid falling into the stereotypes or polemics 